\title{
Rehuannoksen koostumus ja ruokintataso vaikuttavat lypsylehmien rehu- annoksen sulavuuteen
}

\author{
Juha Nousiainen $^{1)}$, Marketta Rinne ${ }^{2)}$ ja Pekka Huhtanen ${ }^{3)}$ \\ ${ }^{1)}$ Valio Oy, Alkutuotanto, PL 10, 00039 Valio, etunimi.sukunimi@valio.fi \\ ${ }^{2)}$ MTT (Maa- ja elintarviketalouden tutkimuskeskus), 31600 Jokioinen, etunimi.sukunimi@mtt.fi \\ ${ }^{3)}$ Ruotsin Maatalousyliopisto (SLU), S-90183 Uumaja, Ruotsi, etunimi.sukunimi@njv.slu.se
}

\section{Tiivistelmä}

Useimmissa rehuarvojärjestelmissä naudoille käytettyjen rehujen energia-arvot pohjautuvat lampailla tehtyihin sulavuuskokeisiin, joissa kyseistä rehua tarjotaan yksinään niin että eläinten ylläpitoenergian tarve täyttyy. Tämä standardoitu sulavuuskoe kuvaa hyvin kullekin rehulle ominaista potentiaalista energia-arvoa märehtijöillä, ts. eläin ei voi valita syömäänsä rehua eikä mikään tekijä vaikututa sulavuutta heikentävästi. Näin saatuja sulavuusarvoja ei voi kuitenkaan suoraan käyttää lypsylehmillä kuvaamaan absoluuttista energiansaantia, koska rehujen välillä on yhdysvaikutuksia ja lehmät syövät 3-4 kertaa enemmän rehua kuin ylläpitoon tarvitaan. Tämän seurauksena lampailla yksittäisten rehujen ylläpitotason sulavuus (OMDm) yliarvioi lehmien sekadieettien (dieetissä sekä väkirehua että karkearehuja) sulavuuden tuotantotasolla (OMDp).

Tämän tutkimuksen tarkoituksena oli kvantifioida rehuannoksen koostumuksen ja ruokintatason vaikutus lypsylehmien rehuannoksen sulavuuteen. Tutkimusaineisto koostui lypsylehmillä suoritetuista tutkimuksista, joissa dieetin sulavuus oli mitattu sonnan kokonaiskeruumenetelmällä tai käyttäen happoon liukenematonta tuhkaa (AIA) merkkiaineena. Kokeissa käytettyjen karkearehujen OMDm määritettiin joko in vivo sulavuuskokeella tai in vitro menetelmillä (sellulaasi- tai pötsineste menetelmä). Väkirehujen OMDm saatiin taulukosta. Tutkimusaineisto koostui 497 ruokinnasta yhteensä 92 kokeessa. Dieettien OMDp ennustettiin käyttämällä SAS sekamalli regressioanlyysiä, jossa koe oli satunnaistekijänä.

Lehmien dieettien OMDp oli vahvasti korreloitunut sulavuuteen ylläpitotasolla (OMDm), mutta kulmakerroin oli merkitsevästi alle 1.00 (0.69, P<0.001). Tämä tarkoittaa että dieetin potentiaalisen sulavuuden noustessa lehmien tuotantotason sulavuus laskee kiihtyvällä tahdilla ylläpitotason sulavuuteen suhteutettuna. Lehmien kuiva-aineen (KA) syönnin lisääntyminen myös merkitsevästi laski sulavuutta (OMDp). Yksinkertainen yhtälö 257( \pm 43$)+0.685( \pm 0.054) \times$ OMDm $(\mathrm{g} / \mathrm{kg} \mathrm{KA})-2.6( \pm 0.44) \times$ KA-syönti (kg/d) ennusti lehmien dieettien sulavuuden hyvin (mallin ennustevirhe $8.4 \mathrm{~g} / \mathrm{kg}$ ).

Lehmien rehuannoksen sulavuus parani väkirehun raakavalkuaispitoisuuden noustessa. Vaikutus ei ollut kvantitatiivisesti suuri, mutta systemaattinen ja tilastollisesti hyvin merkitsevä. Lehmien rehuannoksen väkirehumäärän noustessa OMDp pysyi samana, vaikka ylläpitotasolla määritetty OMDm paranee. Dieetin väkirehun raakarasvan pitoisuuden noustessa OMDp aleni. Sonnan metabolisen orgaanisen aineksen eritys ei ollut riippuvainen dieetin koostumuksesta. Samoin rehuannoksen solunsisällysaineksen sulatus oli lähes täydellistä eikä dieetin koostumuksella eikä ruokintatasolla ollut siihen vaikutusta. Tämä tarkoittaa, että lehmien rehuannoksen orgaanisen aineen sulavuuden (OMDp) vaihtelut johtuvat vaihteluista soluseinäkuidun (NDF) pitoisuudessa ja sulavuudessa.

Johtopäätös tutkimuksesta oli, että lehmien dieetin orgaanisen aineen sulavuus voidaan luotettavasti ennustaa ylläpitotason sulavuudesta (OMDm), kuiva-aineen syönnin määrästä ja dieetin koostumuksesta. Tässä tutkimuksessa estimoitu sulavuuden korjausyhtälö otetaan käyttöön KarjaKompassiohjelmiston ruokinnansuunnitteluohjelmassa, jolloin arviota lehmien energiansaannista maidontuotantovasteiden laskemiseksi pystytään tarkentamaan.

Asiasanat: Karkearehu, väkirehu, sulavuus, ruokintataso, lypsylehmät 


\section{Johdanto}

Useimmissa rehuarvojärjestelmissä naudoille käytettyjen rehujen energia-arvot pohjautuvat lampailla tehtyihin sulavuuskokeisiin, joissa kyseistä rehua tarjotaan yksinään niin että eläinten ylläpitoenergian tarve täyttyy. Tämä standardoitu sulavuuskoe kuvaa parhaiten kullekin rehulle ominaista potentiaalista energia-arvoa märehtijöillä, ts. eläin ei voi valita syömäänsä rehua, eikä mikään tekijä vaikututa sulavuutta heikentävästi. Toisin sanoen standardoitu sulavuuskoe lampailla kuvaa rehun maksimaalista sulavuutta eläimessä (Mertens 1993), ja siihen vaikuttaa eniten rehuannoksen kuidun määrä ja laatu (potentiaalinen sulavuus ja sulavan kuidun sulatusnopeus). Näin saatuja sulavuusarvoja ei voi kuitenkaan suoraan käyttää lypsylehmillä kuvaamaan absoluuttista energiansaantia, koska rehujen välillä on yhdysvaikutuksia ja lehmät syövät 3-4 kertaa enemmän rehua kuin ylläpitoon tarvitaan. Tämän seurauksena lampailla yksittäisten rehujen ylläpitotason sulavuus (OMDm) yliarvioi lehmien sekadieettien (dieetissä sekä väkirehua että karkearehuja) sulavuuden tuotantotasolla (OMDp).

Lehmien rehuannoksen sulavuuden alenema johtuu yleensä väkirehun ja karkearehun negatiivisesta vuorovaikutuksesta, minkä seurauksena kuidun (NDF) sulatus pötsissä alenee. Kuidun sulavuuden aleneminen voimistuu mitä suurempi on rehuannoksen syönti (Mould ym.1983). Väkirehun ja karkearehun välillä voi olla myös positiivista vuorovaikutusta rehun sulatukseen silloin, kun väkirehu täydentää jotain pötsin kuidun sulatuksen minimitekijää. Parhaiten tunnettu positiivinen yhdysvaikutus valkuaislisällä on saatu sulavuuden paraneminen (Oldham 1984). Väki- ja karkearehujen väliset yhdysvaikutukset on kuitenkin puutteellisesti kvantifioitu, jotta malleja voitaisiin käyttää nykyisten rehuarvojärjestelmien kehittämiseksi ja apuna lehmin ruokinnan suunnittelussa.

Tämän tutkimuksen tarkoituksena oli kvantifioida rehuannoksen koostumuksen ja ruokintatason vaikutus lypsylehmien rehuannoksen sulavuuteen. Tavoitteena oli selvittää lehmien sulatukseen vaikuttavia karkearehu- (sulavuus ja käymislaatu) ja väkirehutekijöitä (väkirehun määrä, hiilihydraattikoostumus sekä valkuaispitoisuus). Lisäksi tavoitteena oli kvantifioida ruokintason vaikutus sulavuuteen ja tuottaa käytännön ruokinnan suunnittelua varten malli jolla voidaan rehukohtaisista ylläpitotason sulavuusluvuista (OMDp) laskea sekadieetin sulavuus lypsylehmillä tuotantotasolla (OMDp). Tämä kirjoitus perustuu Nousiaisen ym. (2009) ja Huhtasen ym. (2009) artikkeleihin.

\section{Aineisto ja menetelmät}

Tutkimusaineisto (Taulukko 1) koostui lypsylehmillä suoritetuista tutkimuksista, joissa karkearehuna oli nurmisäilörehu. Osassa kokeista nurmisäilörehu oli osittain tai kokonaan korvattu palkokasvisäilörehulla (puna-apila useimmiten) tai kokoviljasäilörehulla. Väkirehulisä vaihteli määrän, hiilihydraattikoostumuksen ja valkuaispitoisuuden osalta. Lehmien koko dieetin sulavuus (OMDp) oli mitattu sonnan kokonaiskeruumenetelmällä $(\mathrm{n}=176)$ tai käyttäen happoon liukenematonta tuhkaa (AIA) merkkiaineena $(\mathrm{n}=321)$. Kokeissa käytettyjen karkearehujen OMDm määritettiin joko in vivo sulavuuskokeella tai in vitro menetelmillä (sellulaasi- tai pötsineste -menetelmä). Väkirehujen OMDm saatiin rehutaulukosta (MTT 2006). Tutkimusaineisto koostui yhteensä 497 ruokinnasta 92 kokeesta. Dieettien OMDp ennustettiin käyttämällä SAS sekamalli regressioanalyysiä, jossa koe oli satunnaistekijänä. Perusmallissa oli mukana OMDm ja lehmien rehuannoksen KA-syönti, mutta lisäksi mallissa käytettiin selittäjinä muita dieettitekijöitä. Koko aineisto jaettiin osa-aineistoihin kokeista, joissa oli tutkittu säilörehun sulavuuden (42 dieettiä/17 koetta) ja käymislaadun (108/39) sekä väkirehumäärän (142/59), väkirehun hiilihydraattikoostumuksen (66/23) ja valkuaispitoisuuden (215/82) vaikutuksia lehmien rehunsyöntiin ja dieetin sulavuuteen. Osa-aineistoilla pyrittiin selvittämään lehmien rehuannoksen sulatukseen vaikuttavia mekanismeja.

\section{Tulokset ja niiden tarkastelu}

Lypsylehmien sekadieettien orgaanisen aineen (OA) sulavuuden vaihtelu selittyy lähes kokonaan kuidun (NDF) määrällä ja sen sulavuuden vaihtelulla. Tämä johtuu siitä, että solusisällysaineiden (eli NDS = OA-NDF) todellinen sulavuus on lähes täydellinen (0.975, Taulukko 2). Sontaan erittyvä metaboolisen aineen määrä (MFOA) oli koko aineistossa keskimäärin 84 g/kg KA. Karkearehun laatu (sulavuus, käymislaatu) ja väkirehun määrä tai laatu ja kokonaissyönti eivät vaikuttaneet NDS:n sulavuuteen eikä MFOA:n määrään. Tämän ns. Lucasin testin tulokset olivat samanlaiset kuin lampailla eri karkearehuja sisältävässä aineistossa (Huhtanen ym. 2006) ja sekadieeteillä (Weisbjerg ym. 2004) ylläpitotasoruokinnalla tehdyissä sulavuuskokeissa. 
Taulukko 1. Tutkimusaineiston tilastollinen kuvailu

\begin{tabular}{|c|c|c|c|c|c|}
\hline & $\mathrm{n}$ & Keskiarvo & Keskihajonta & Min & Maks \\
\hline \multicolumn{6}{|l|}{ Syönti (kg KA/pv) } \\
\hline Karkearehu & 497 & 10.9 & 1.93 & 4.6 & 17.4 \\
\hline Väkirehu & 497 & 7.7 & 2.47 & 0.0 & 18.4 \\
\hline Yhteensä & 497 & 18.6 & 2.98 & 9.9 & 25.2 \\
\hline \multicolumn{6}{|l|}{ Tuotanto (kg/pv) } \\
\hline Maito & 497 & 26.7 & 5.06 & 13.0 & 45.8 \\
\hline EKM & 497 & 27.4 & 5.33 & 12.8 & 42.1 \\
\hline \multicolumn{6}{|l|}{ Sulavuus (g/kg) } \\
\hline Orgaaninen aine (OA) & 497 & 736 & 38.1 & 621 & 830 \\
\hline Raakavalkuainen (RV) & 471 & 691 & 41.1 & 542 & 782 \\
\hline Kuitu (NDF) & 388 & 627 & 71.8 & 408 & 830 \\
\hline $\mathrm{pdNDF}^{1}$ & 388 & 754 & 63.3 & 506 & 946 \\
\hline $\operatorname{MFOM}^{2}$ (g/kg KA) & 388 & 96 & 14.6 & 61 & 147 \\
\hline \multicolumn{6}{|c|}{ Rehuannoksen koostumus (g/kg KA) } \\
\hline RV & 497 & 166 & 20.0 & 111 & 229 \\
\hline NDF & 497 & 419 & 47.0 & 283 & 559 \\
\hline Sulamaton NDF & 497 & 68 & 22.4 & 19 & 148 \\
\hline Raakarasva & 497 & 44 & 10.1 & 22 & 112 \\
\hline Tärkkelys & 497 & 141 & 56.3 & 0 & 292 \\
\hline Säilörehun sokeri $^{3}$ & 406 & 54 & 40.0 & 1 & 175 \\
\hline Säilörehun käymishapot ${ }^{4}$ & 451 & 76 & 33.7 & 7 & 218 \\
\hline $\mathrm{OMD}_{\mathrm{m}}{ }^{5}(\mathrm{~g} / \mathrm{kg})$ & 497 & 774 & 31.5 & 658 & 846 \\
\hline
\end{tabular}

${ }^{1}$ pdNDF = potentiaalisesti sulava kuitu (NDF)

${ }^{2} \mathrm{MFOM}=$ sonnan metaboolinen orgaaninen aine (OA - NDF)

${ }^{3}$ Vesiliukoiset hiilihydraatit

${ }^{4}$ Maitohappo+haihtuvat rasvahapot

${ }^{5} \mathrm{OMD}_{\mathrm{m}}=$ rehuannoksen OA:n laskennallinen sulavuus perustuen karkearehun mitattuun sulavuuteen tai väkirehujen taulukkosulavuuteen.

Lehmien sekadieettien kuidun sulavuus riippuu rehukasvin kuidun ominaisuuksista, jotka määräävät kuidun maksimaalisen sulavuuden sekä dieetin koostumuksesta ja ruokintatasosta, joka ratkaisee sen mikä osuus maksimaalisesta kuidun sulavuudesta saavutetaan (Mertens 1993). Osa dieetin kuidusta (NDF) on täysin sulamatonta (iNDF, Taulukko 1) ja osa potentiaalisesti sulavaa (pdNDF = NDF - iNDF), ts. koko dieetin orgaanisen aineen (OA) sulavuuden vaihtelu johtuu pääosin kuidun määrästä sekä pdNDF:n sulavuudesta, johon vaikuttavat sen viipymäaika ja sulatusnopeus pötsissä. Tässä aineistossa pdNDF:n keskimääräinen sulavuus oli 754 g/kg ja vaihteli välillä 408-820 g/kg. Lampailla karkearehuaineistossa (Huhtanen ym. 2006) pdNDF:n sulavuus oli keskimäärin 850 g/kg. Lehmien tuotantotason sekadieettien ja lampaiden yp- tason (ylläpitotaso) pdNDF:n sulavuusero kuvaa sitä potentiaalisesti sulavan kuidun määrä, joka lypsylehmillä menetetään sontaan korkeamman ruokintatason sekä väkirehun ja karkearehun sulatuksen negatiivisten yhdysvaikutusten vuoksi. Nimenomaan suomalaisilla dieeteillä, jotka perustuvat hyvälaatuiseen karkearehuun ja viljaan, pdNDF:n sulatuserot lypsylehmillä voivat olla merkittävän suuret johtuen karkearehun kuidun sulavuudesta sekä väkirehun koostumuksesta ja määrästä (Nousiainen ym. 2009; Huhtanen ym. 2009).

Lehmien dieettien OMDp oli vahvasti korreloitunut sulavuuteen ylläpitotasolla (OMDm), mutta kulmakerroin oli merkitsevästi alle 1 (0.642, $\mathrm{P}<0.001$, Kuvio 1). Huomionarvoista tuloksissa oli myös se, että Kuvion 1 regression parametrit olivat käytännössä samantasoiset riippumatta siitä, oliko dieetin karkearehuosan OMDm määritetty lampailla sulavuuskokeessa tai in vitro menetelmillä perustuen pötsinesteeseen (Tilley \& Terry 1963) tai entsyymiliukoisuuteen (Nousiainen ym. 2003). Tämä on merkittävää nimenomaan siksi, että käytännön karkearehurehuanalytiikka perustuu entsyymiliukoisuuden avulla kalibroituihin NIR-laitteisiin (Huhtanen ym. 2006). 
Taulukko2. Lucasin ${ }^{1}$ testi solunsisällysaineille $\left(\mathrm{NDS}^{2}, \mathrm{~g} / \mathrm{kg} \mathrm{ka)} \mathrm{lypsylehmien} \mathrm{sekadieeteillä}\right.$

\begin{tabular}{|c|c|c|c|c|c|c|c|}
\hline Aineisto & $\mathrm{n}$ & $\begin{array}{l}\text { Leikkaus- } \\
\text { piste }\end{array}$ & SE & $\begin{array}{l}\text { Kulma- } \\
\text { kerroin }\end{array}$ & SE & P-arvo & RMSE \\
\hline Säilörehun kasvuaste & 36 & -82.3 & 29.0 & 0.973 & 0.056 & $<0.001$ & 3.50 \\
\hline Väkirehutaso & 110 & -88.4 & 11.8 & 0.990 & 0.024 & $<0.001$ & 5.12 \\
\hline Väkirehun hh-koostumus ${ }^{3}$ & 38 & -128 & 15.1 & 1.034 & 0.029 & $<0.001$ & 5.30 \\
\hline Koko aineisto & 388 & -84.0 & 10.0 & 0.975 & 0.021 & $<0.001$ & 5.80 \\
\hline
\end{tabular}

${ }^{1}$ Lucasin testissä regressiossa näennäisesti sulavan dieetin komponentin määrää (sulava NDS) selitetään ko. komponentin määrällä (NDS). Regression kulmakerroin kuvaa dieetin komponentin todellista sulavuutta ja leikkauspiste sontaan erittyneen metaboolisen aineen määrää (g/kg KA)

${ }^{2} \mathrm{NDS}=$ orgaaninen aine $-\mathrm{NDF}$

${ }^{3}$ Kokeet joissa viljaväkirehu oli korvattu kokonaan tai osittain kuitupitoisilla väkirehuilla

Keskimäärin lehmien dieettien OMDp oli $38 \mathrm{~g} / \mathrm{kg}$ alempi kuin lampaiden yp-tasolla määritetty OMDm (Taulukko 1). Dieetin potentiaalisen sulavuuden (OMDm) noustessa lehmien tuotantotason sulavuus (OMDp) laskee kiihtyvällä tahdilla ylläpitotason sulavuuteen suhteutettuna (Kuvio 1). Lehmien kuiva-aineen syönnin lisääntyminen myös merkitsevästi laski sulavuutta (OMDp). Yksinkertainen yhtälö $257( \pm 43)+0.685( \pm 0.054) \times$ OMDm $(\mathrm{g} / \mathrm{kg} \mathrm{KA})-2.6( \pm 0.44) \times \mathrm{KA}$-syönti $(\mathrm{kg} / \mathrm{d})$ ennusti lehmien dieettien sulavuuden hyvin (mallin ennustevirhe $8.4 \mathrm{~g} / \mathrm{kg}$ ). Yhtälö kuvaa sitä, että keskimääräin 69\% OMDm:n paranemisesta realisoituu lypsylehmillä ja että yhden kuiva-ainekilon syönnin lisäys päivässä laskee sulavuutta 2,6 g/kg. Kuiva-ainesyönnin toisen asteen polynomi regressiossa oli suuntaa-antavasti käyräviivainen $(\mathrm{P}=0.07)$. Käyräviivaisuus merkitsisi sitä, että ruokintatason sulavuutta alentava vaikutus jopa hieman lisääntyy korkeammilla syöntitasoilla. Esimerkiksi amerikkalaisessa NRC:n (2001) järjestelmässä ruokintatason vaikutus oletetaan käyräviivaiseksi. Tämä todennäköisesti johtuu siitä, että väkirehutason ja syönnin lisääntyessä maissitärkkelyksen eritys sontaan lisääntyy. Mahdollisesti juuri tästä syystä johtuen tässä aineistossa käyräviivaisuus oli varsin vähäistä (Kuvio 1), koska dieetit perustuivat pääosin nurmisäilörehuun ja rehuviljaan eikä maissitärkkelystä ollut kuin yksittäisissä dieeteissä.

Eri dieettitekijöiden vaikutus lehmien rehuannoksen sulavuuteen lypsylehmillä on esitetty Taulukossa 3. Säilörehun yp-sulavuuden (OMDm) parantuessa yhdellä yksiköllä, parani lehmien OMDp 0.52 yksikköä. Koska karkearehun osuus dieeteissä oli n. 40 \%, tulos tarkoittaa sitä että karkearehun korjuuastetta aikaistamalla saavutettu sulavuuden paraneminen realisoituu lähes täysin lypsylehmien sekadieeteillä. Samaan tulokseen on päätynyt mm. Rinne (2000) pienemmällä aineistolla. Sulavuuden paraneminen johtuu sekä pienemmästä dieetin kuidun määrästä että paremmasta kuidun laadusta (pienempi iNDF pitoisuus ja suurempi pdNDF:n sulatusnopeus).

Säilörehun käymislaadulla oli pienehkö vaikutus sulavuuteen lehmillä. Tämä johtui pääosin siitä että rajoitettu käyminen laski lievästi pdNDF:n sulavuutta. Mahdollisesti kyse on siitä, että rajoittuneesti käyneen säilörehun sokeri voi alentaa hivenen kuidun sulatusta. Mutta vaikka vaikutus oli tilastollisesti merkitsevä $(\mathrm{P}<0.001)$, lehmien energian saannin kannalta sen merkitys on vähäinen suhteessa rajoittuneesti käyneen säilörehun suurempaan syöntipotentiaaliin (Huhtanen ym. 2007).

Lisättäessä väkirehun määrää dieetissä paranee sen OMDm, koska kuidun (NDF) ja sulamattoman kuidun (iNDF) pitoisuus dieetissä vähenee. Tämän aineiston tulosten mukaan kuitenkin lehmien sekadieettien OMDp ei parantunut väkirehutason noustessa (Taulukko 3). Mikäli dieetin laadun (OMDm) paraneminen huomioitiin kahden tekijän regressiossa, alensi yksi väkirehukilo sulavuutta (OMDp) 3.2 g/kg (Taulukko 3). Tulos siis tarkoittaa, että dieetin täysin sulavan NDS:n määrän lisääntyessä korkeammilla väkirehutasoilla, lisääntyvä osa potentiaalisesti sulavasta kuidusta menetetään sontaan. Toisin sanoen pdNDF:n sulavuus laskee. Tässä aineistossa lasku oli 10.3 g/kg yhtä lisäväkirehukiloa kohden. Jos dieetti sisältää hyvälaatuista nurmirehua, on hyvin todennäköistä että lisäväkirehulla ei saavuteta OMDp:n paranemista, vaan lisätuotos perustuu pelkästään dieetin parempaan syöntipotentiaaliin täyttävyyden laskiessa (Huhtanen ym. 2008). Aston ym. (1994) vertasivat väkirehulisän vaikutusta lehmien OMDp:hen, ja havaitsivat että syötettäessä lehmille hyvälaatuista nurmirehua dieettien sulavuus aleni väkirehutason noustessa, mutta huonolaatuisempaa sinimailasrehua syötettäessä OMDp parani. Tulos tarkoittaa käytännössä, että haluttaessa maksimoida nurmisäilörehulla 


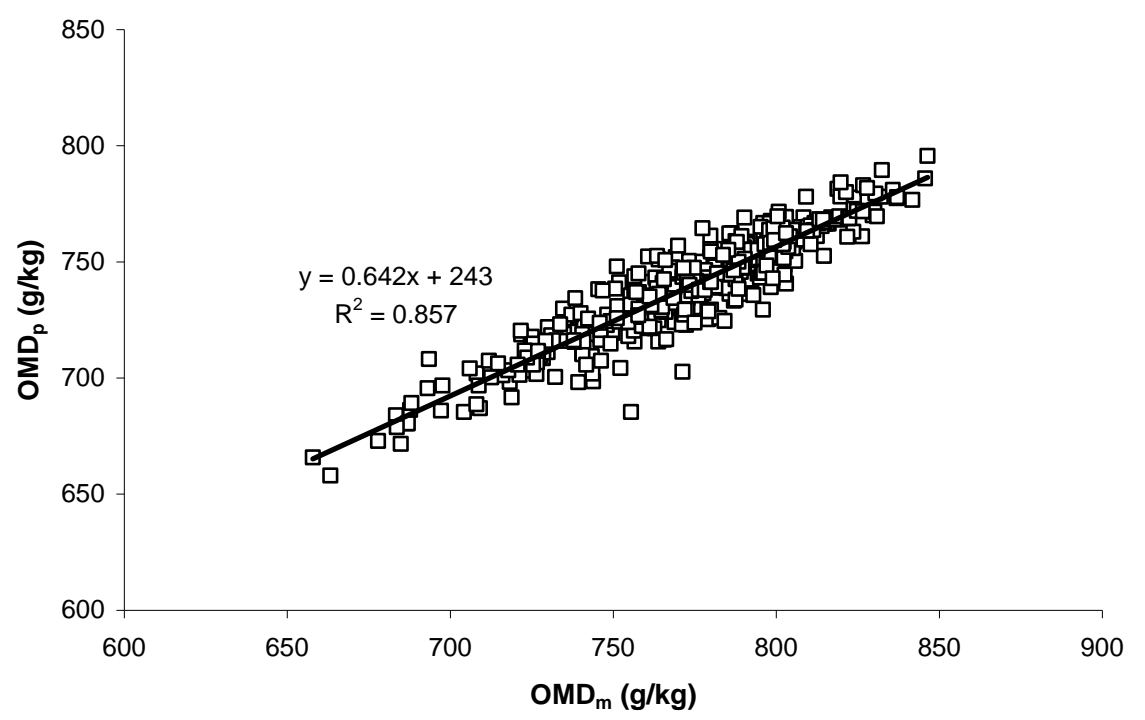

Kuvio 1. Lehmien sekadieettien ylläpitotasosulavuuden (OMDm) ja tuotantokokeissa mitatun sulavuuden (OMDp) välinen yhteys $(\mathrm{n}=497)$

tuotettu maitomäärä, tulee väkirehutaso pitää kohtuullisena. Potentiaalisesti sulavan kuidun sulatuksen huononeminen väkirehutasoa nostettaessa johtuu todennäköisesti kuitua sulattavien bakteerien kasvuolosuhteiden huononemisesta, kun pötsin happamuus lisääntyy.

Tässä meta-analyysissa lehmien rehuannoksen sulavuus parani mitä suurempi oli väkirehuosan raakavalkuaisen (RV) pitoisuus. Vaikutus ei ollut kvantitatiivisesti suuri, mutta systemaattinen ja tilastollisesti hyvin merkitsevä (Taulukko 3). Yksittäisissä ruokintatutkimuksissa lehmien dieetin OMDp:n paranemista on hyvin harvoin havaittu. Väkirehun valkuaislisän vaikutus oli tässä tutkimuksessa merkitsevästi käyräviivainen. Väkirehun RV-pitoisuuden noustessa tasolta 130 tasolle 180 g/kg KA, aleni dieetin OA:n sulavuutta parantava vaikutus puoleen ( 0.41 vs. $0.21 \mathrm{~g} / \mathrm{kg}$ per $1 \mathrm{~g}$ RV $/ \mathrm{kg} \mathrm{KA}$ ). Orgaanisen aineen sulavuuden nousu johtui hyvin todennäköisesti pdNDF:n paremmasta sulavuudesta, koska dieetin iNDF-pitoisuus nousi samanaikaisesti. Tämä johtunee siitä, että useissa kokeissa valkuaisrehuna käytetyn rypsin kuitu on huonosti sulavaa. Potentiaalisesti sulavan kuidun sulavuuden paraneminen voi johtua siitä että pötsibakteerien typen ja aminohappojen saanti paranee ja/tai kuidun sulatuksen kannalta pötsiolosuhteiden paranemisesta (pienempi happamuus) ja nopeampi kuidun sulatusnopeus.

Korvattaessa tärkkelyspitoisia viljaväkirehua kuitupitoisilla väkirehuilla on monessa yksittäisessä tutkimuksessa havaittu sekä kuidun (NDF) että pdNDF:n sulavuuden paraneminen. Myös tässä aineistossa pdNDF:n sulavuus parani $0.14 \mathrm{~g} / \mathrm{kg}$ dieetin väkirehun kuitupitoisuuden noustessa $1 \mathrm{~g} / \mathrm{kg}$ KA (Taulukko 3). Hyvin todennäköisesti tämä johtuu dieetin tärkkelyspitoisuuden alenemisesta ja paremmista pötsiolosuhteista kuidun sulatukselle. On kuitenkin epätodennäköistä että pdNDF:n paraneminen nostaisi OMDp:tä, ja se voi jopa laskea, koska varsinkin korkeilla ruokinta- ja väkirehutasoilla väkirehun kuidun viipymäaika pötsissä lyhenee, jolloin väkirehun kuidun sulavuus alenee. Tässä aineistossa lehmien dieettien OMDp aleni väkirehun kuidun määrän lisääntyessä dieeteissä kokeissa joissa tärkkelyspitoinen väkirehu korvattiin osittain tai kokonaan kuitupitoisilla väkirehuilla.

Tämän tutkimuksen tulokset osoittavat selkeästi, että lehmien sekadieettien sulavuus (OMDp) voidaan ennustaa varsin luotettavasti dieetin komponenttien yp-sulavuuden (OMDm) ja kuiva-aineen syönnin avulla. Ennustetta voidaan jonkun verran parantaa lisäämällä muita dieettitekijöitä malliin (Taulukko 4), vaikka vain väkirehun valkuaispitoisuuden lisääminen paransi merkittävästi sulavuusennusteiden tarkkuutta. Muita merkitseviä tekijöitä mallissa ovat kokoviljasäilörehun osuus ja väkirehun rasvan määrä dieetissä. Nurmisäilörehun korvaaminen kokoviljasäilörehulla paransi OMDp:tä kun sen osuus karkearehusta oli alle 0.18, mutta tätä suurempi korvausaste huononsi OMDp:tä. Väkirehun rasvapitoisuus taas alensi sulavuutta (OMDp) $18 \mathrm{~g} / \mathrm{kg}$ kun väkirehun rasvan pitoisuus lisääntyi dieetissä $1 \mathrm{~g} / \mathrm{kg}$ ka. 
Taulukko 3. Eri dieettitekijöiden vaikutus lehmien rehuannoksen orgaanisen aineen (OA), kuidun (NDF) ja potentiaalisesti sulavan kuidun (pdNDF) sulavuuteen $(\mathrm{g} / \mathrm{ka})$

\begin{tabular}{|c|c|c|c|c|c|c|c|c|c|c|}
\hline $\begin{array}{l}\text { Sula- } \\
\text { vuus }\end{array}$ & Aineisto & $\mathrm{n}$ & Tekijä1 & Tekijä2 & $\begin{array}{l}\text { Leikkaus- } \\
\text { piste }\end{array}$ & $\begin{array}{l}\text { Kulma- } \\
\text { kerroin1 }\end{array}$ & P-arvo & $\begin{array}{l}\text { Kulma- } \\
\text { kerroin2 }\end{array}$ & P-arvo & RMSE \\
\hline OA & $\begin{array}{l}\text { Säilörehun kasvu- } \\
\text { aste }\end{array}$ & 44 & OMDm & & 372 & 0.515 & $<0.001$ & & & 6.6 \\
\hline NDF & $\begin{array}{l}\text { Säilörehun kasvu- } \\
\text { aste }\end{array}$ & 36 & OMDm & & 115 & 0.757 & $<0.001$ & & & 8.2 \\
\hline pdNDF & $\begin{array}{l}\text { Säilörehun kasvu- } \\
\text { aste }\end{array}$ & 36 & OMDm & & 364 & 0.202 & 0.002 & & & 12.3 \\
\hline $\mathrm{OA}$ & $\begin{array}{l}\text { Karkearehun käy- } \\
\text { mislaatu }\end{array}$ & 92 & TA & & 726 & 0.03 & 0.530 & & & 5.9 \\
\hline NDF & $\begin{array}{l}\text { Karkearehun käy- } \\
\text { mislaatu } \\
\text { Karkearehun käy- }\end{array}$ & 80 & TA & & 617 & 0.18 & 0.005 & & & 12.3 \\
\hline pdNDF & mislaatu & 80 & Sokeri & & 646 & -0.22 & $<0.001$ & & & 14.0 \\
\hline OA & Väkirehutaso & 142 & VRKAs & OMDm & 119 & -3.2 & $<0.001$ & 0.83 & $<0.001$ & 5.58 \\
\hline NDF & Väkirehutaso & 110 & VRKAs & $\mathrm{pdNDF} / \mathrm{NDF}$ & 208 & -7.9 & $<0.001$ & 1.09 & $<0.001$ & 12.0 \\
\hline pdNDF & Väkirehutaso & 110 & VRKAs & & 842 & -10.3 & $<0.001$ & & & 13.6 \\
\hline $\mathrm{OA}$ & Valkuaislisäkokeet & 224 & $\mathrm{RV}$ & $\mathrm{RV} \times \mathrm{RV}$ & 638 & 0.93 & $<0.001$ & -0.002 & 0.06 & 4.0 \\
\hline NDF & Valkuaislisäkokeet & 182 & $\mathrm{RV}$ & & 508 & 0.77 & $<0.001$ & & & 9.5 \\
\hline pdNDF & $\begin{array}{l}\text { Valkuaislisäkokeet } \\
\text { Väkirehun hh- }\end{array}$ & 182 & $\mathrm{RV}$ & & 585 & 1.15 & $<0.001$ & & & 12.5 \\
\hline OA & $\begin{array}{l}\text { kokeet } \\
\text { Väkirehun hh- }\end{array}$ & 66 & vrNDF & & 769 & -0.091 & 0.007 & & & 3.5 \\
\hline NDF & $\begin{array}{l}\text { kokeet } \\
\text { Väkirehun hh- }\end{array}$ & 38 & vrNDF & & 604 & -0.077 & 0.001 & & & 8.4 \\
\hline pdNDF & kokeet & 38 & vrNDF & & 736 & 0.135 & 0.055 & & & 8.4 \\
\hline
\end{tabular}

${ }^{1} \mathrm{OMD}_{\mathrm{m}}=$ rehuannoksen orgaanisen aineen laskennallinen sulavuus perustuen karkearehun mitattuun sulavuuteen ja väkirehujen taulukkosulavuuteen $(\mathrm{g} / \mathrm{kg})$

${ }^{2} \mathrm{TA}=$ säilörehun käymishappojen määrä (g/kg KA; koko dieetti)

${ }^{3}$ VRKAs = väkirehun kuiva-aineen syönti (kg KA/pv)

${ }^{4} \mathrm{vrNDF}=$ äkirehun kuitupitoisuus (g/kg KA)

Dieetin NDF:n sulavuuden ennustemalli on esitetty Taulukossa 5. Malli sisälsi sekä dieetin laatuun vaikuttavia rehujen sisäisiä tekijöitä, että lehmien ruokinnan managementtitekijöitä. Dieetin laatua kuvaavista tekijöistä tärkein oli pdNDF/NDF suhde, joka on siis jokaiselle rehukasville tyypillinen ominaisuus ja kuvaa rehujen kuidun potentiaalista käyttökelpoisuutta. Kuiva-aineen syönnin lisääntyessä kuidun sulavuus aleni 4.9 g/kg per 1 kg KA/pv. Solunsisällyshiilihydraattien ja kokoviljasäilörehun osuus karkearehusta alensivat kuidun sulavuutta käyräviivaisesti ja väkirehun rasvan saanti lineaarisesti. Väkirehun valkuaisen lisäys paransi myös kuidun sulavuutta.

\section{Johtopäätökset}

Lehmien dieetin orgaanisen aineen sulavuus voidaan luotettavasti ennustaa ylläpitotason sulavuudesta (OMDm), kuiva-aineen syönnin määrästä ja dieetin koostumuksesta. Tässä tutkimuksessa estimoitu sulavuuden korjausyhtälö otetaan käyttöön KarjaKompassi-ohjelmiston ruokinnansuunnitteluohjelmassa, jolloin arviota lehmien energiansaannista maidontuotantovasteiden laskemiseksi pystytään tarkentamaan. 
Taulukko 4. Paras regressiomalli lehmien sekadieettien orgaanisen aineen sulavuuden (OMDp) ennustamiseksi (n=497, adj.RMSE 7,1 g/kg, ei-adj. RMSE $21.6 \mathrm{~g} / \mathrm{kg}$ )

\begin{tabular}{lcccc}
\hline Vaikutus & Yksikkö & Estimaatti & SE & P-arvo \\
\hline Leikkauspiste & & 18.4 & 54 & 0.73 \\
OMD $^{1}{ }^{1}$ & g/kg KA & 0.651 & 0.06 & $<0.001$ \\
KAs & $\mathrm{kg} / \mathrm{pv}$ & -2.72 & 0.56 & $<0.001$ \\
Ln RV & g/kg KA & 53.7 & 6.1 & $<0.001$ \\
WCrop $^{2}$ & osuus & 22.2 & 20 & 0.37 \\
WCrop $^{2}$ WCrop & osuus & -61.4 & 21 & 0.003 \\
Raakarasva & g/kg KA & -17.7 & 6 & 0.002 \\
\hline
\end{tabular}

${ }^{1} \mathrm{OMDm}$ = rehuannoksen orgaanisen aineen laskennallinen sulavuus perustuen karkearehun mitattuun sulavuuteen ja väkirehujen taulukkosulavuuteen.

${ }^{2}$ WCrop = kokoviljasäilörehun osuus karkearehusta

Taulukko 5. Paras regressiomalli lehmien sekadieettien kuidun (NDF) sulavuuden ennustamiseksi (n=394, adj.RMSE 12,4 g/kg, ei-adj. RMSE $40.1 \mathrm{~g} / \mathrm{kg}$ )

\begin{tabular}{|c|c|c|c|c|}
\hline Vaikutus & Yksikkö & Estimaatti & SE & P-arvo \\
\hline Leikkauspiste & & -285 & 130 & 0.03 \\
\hline $\mathrm{pdNDF}^{1} / \mathrm{NDF}$ & $\mathrm{g} / \mathrm{kg} \mathrm{NDF}$ & 0.647 & 0.131 & $<0.0001$ \\
\hline KAs & $\mathrm{kg} / \mathrm{pv}$ & -4.85 & 1.43 & $<0.0001$ \\
\hline WCrop $^{2}$ & osuus & -28 & 39.2 & $<0.48$ \\
\hline WCrop $\times$ WCrop & osuus & -70 & 39.3 & 0.08 \\
\hline$\left(\mathrm{NFC}^{3} / \mathrm{NDF}\right) \times(\mathrm{NFC} / \mathrm{NDF})$ & & -55 & 6.8 & $<0.0001$ \\
\hline LnRV & g/kg KA & 101 & 14.3 & $<0.0001$ \\
\hline Raakarasva & $\mathrm{kg} / \mathrm{pv}$ & -33 & 15.6 & 0.04 \\
\hline
\end{tabular}

\section{Kirjallisuus}

Aston, K., Thomas, C., Daley, S. R., Sutton, J. D. \& Dhanoa, M. S. 1994b. Milk production from grass silage diets: Effects of silage characteristics and the amount of concentrate. Anim. Prod. 59:31-41.

MTT. 2006. Rehutaulukot ja ruokintasuositukset -verkkopalvelu. Viitattu 10.11.2009.

www.mtt.fi/rehutaulukot

Huhtanen, P., Nousiainen, J. \& Rinne, M. 2006. Recent developments in forage evaluation with special reference to practical applications. Agricultural and Food Science 15: 293-323.

Huhtanen, P., M. Rinne, \& Nousiainen, J.. 2007. Evaluation of the factors affecting silage intake of dairy cows: A revision of the relative silage dry matter intake index. Animal 1:758-770.

Huhtanen, P., Rinne, M. \& Nousiainen, J. 2008. Evaluation of concentrate factors affecting silage intake of dairy cows: a development of the relative total diet intake index. Animal 2: 942-935.

Huhtanen, P., M. Rinne, \& Nousiainen, J. 2009. A meta-analysis of feed digestion in dairy cows. 2. The effects of feeding level and diet composition on digestibility. J. Dairy Sci. 92:5031-5042.

Mertens, D. R. 1993. Kinetics of cell wall digestion and passage in ruminants. Pages 535-570 in Forage Cell Wall Structure and Digestibility. H. G. Jung, D. R. Buxton, R. D. Hatfield, and J.Ralph, ed. Am. Soc. Agron., Madison, WI.

Mould, F. L., E. R. Ørskov \& Mann, S. O. 1983. Associative effects of mixed feeds. I. Effects of type and level of supplementation and the influence of the rumen $\mathrm{pH}$ on cellulolysis in vivo and dry matter digestion of various roughages. Anim. Feed Sci. Technol. 10:15-30. 
Nousiainen, J., Rinne, M., Hellämäki, M. \& Huhtanen, P. 2003. Prediction of the digestibility of the primary growth of grass silages harvested at different stages of maturity from chemical composition and pepsin-cellulase solubility. Animal Feed Science and Technology 103: 97-111.

Nousiainen, J., P. Huhtanen, \& M. Rinne. 2009. A meta-analysis of feed digestion in dairy cows. 1. The effect of forage and concentrate factors on total diet digestibility. J. Dairy Sci. 92: 5019-530.

NRC. 2001. Nutrient Requirements of Dairy Cattle. 7th rev. ed. Natl. Acad. Press, Washington, DC.

Rinne, M. 2000. Influence of the timing of the harvest of primary grass growth on herbage quality and subsequent digestion and performance in the ruminant animal. University of Helsinki, Department of Animal Science. Publications 54. 42 p. +5 encl. Academic dissertation. Available at: http://ethesis.helsinki.fi/julkaisut/maa/kotie/vk/rinne.

Oldham, J. D. 1984. Protein energy relationships in dairy cows. J. Dairy Sci. 67:1090-1114.

Tilley, J., \& R. Terry. 1963. A two-stage technique for the in vitro digestion of forage crops. J. Br. Grassl. Soc. 18:104-111.

Weisbjerg, M. R., T. Hvelpund, and K. Søegaard. 2004. Prediction of digestibility of neutral detergent solubles using the Lucas principle. J. Anim. Feed Sci. 13(Suppl. 1):239-242. 